\title{
Genetic variability of the components of seed yield in interspecific hybrids of Paspalum
}

\author{
Rodrigo Ramos Lopes ${ }^{1 *}$, Cleber Henrique Lopes de Souza ${ }^{2}$, Emerson André Pereira ${ }^{3}$, Bruno \\ Frosi Gasparetto ${ }^{2}$, Miguel Dall'Agnol', Lucia Brandão Franke ${ }^{1}$
}

\footnotetext{
${ }^{1}$ Universidade Federal do Rio Grande do Sul, Faculdade de Agronomia, Departamento de Plantas Forrageiras e Agrometeorologia, Porto Alegre, RS, Brazil.

${ }^{2}$ Universidade Federal do Rio Grande do Sul, Programa de Pós-graduação em Zootecnia, Porto Alegre, RS, Brazil.

${ }^{3}$ Universidade Regional do Noroeste do Estado do Rio Grande do Sul, Departametno de Estudos Agrários, ljuí, RS, Brazil.
}

\begin{abstract}
This study aimed to determine the variability and expression of the components of seed yield in twenty-three apomictic Paspalum plicatulum $\times$ Paspalum lepton hybrids and two male parent plants (P. lepton). We used a randomized block design with genotypes individually arranged into ten blocks. The variables were: number of total tillers/plant, number of vegetative tillers/plant, number of reproductive tillers/plant, percentage of reproductive tillers, number of racemes/inflorescence, number of seeds/inflorescence, weight of a thousand seeds, and seed yield. We assessed genetic variability using multivariate procedures: generalized Mahalanobis distance, Tocher's clustering optimization method, and quantification of the relative contribution of the variables. The quantification of variability, based on the components of seed yield of Paspalum plicatulum $\times$ Paspalum lepton hybrids, allows the formation of six groups of genotypes using Tocher's method, with high means for the characteristics studied. Weight of a thousand seeds and number of seeds/inflorescence were the traits that most contributed to the genetic dissimilarity. Genetic crosses involving genotype 10E5052 from group VI and 10E4071 from group V could be undertaken to isolate high yielding segregants, since these genotypes have high seed yielding potential.
\end{abstract}

Key Words: apomitic genotypes, Plicatula, seed production, weight of thousand seeds

\section{Introduction}

The genus Paspalum contains a large number of species considered excellent forage, not only for their ecological and forage importance, but for significant heterogeneity: apomixis, polyploidy, and interspecific hybridization (Fonseca and Martuscello, 2010).

Most Paspalum species reproduce by apomixis (Quarín and Normann, 1990), hampering genetic recombination and the protection of cultivars under current legal standards (Pereira et al., 2012). However, the use of hybrids, when one of the parent plants exhibits sexual reproduction, can generate variability and enable the selection of elite progeny, with immediate fixation of characteristics of interest due to apomixis (Acuña et al., 2009).

Received: September 27, 2016

Accepted: January 19, 2017

*Corresponding author: lopezhsf@hotmail.com

http://dx.doi.org/10.1590/S1806-92902017000400004

How to cite: Lopes, R. R.; Souza, C. H. L.; Pereira, E. A.; Gasparetto, B. F.; Dall'Agnol, M. and Franke, L. B. 2017. Genetic variability of the components of seed yield in interspecific hybrids of Paspalum. Revista Brasileira de Zootecnia 46(4):296-302.

Copyright (C) 2017 Sociedade Brasileira de Zootecnia. This is an Open Access article distributed under the terms of the Creative Commons Attribution License (http://creativecommons.org/licenses/by/4.0/), which permits unrestricted use, distribution, and reproduction in any medium, provided the original work is properly cited.
The discovery of sexually reproducing diploid plants in natural populations of Paspalum plicatulum made it possible to obtain new genotypes by crossbreeding with compatible species (Sartor et al., 2009), opening a vast array of possibilities in the genetic improvement of this species.

According to Martiniello and Silva (2011), in crops in which grain is the main product, selection to improve the mobilization efficiency of photoassimilates for these organs has been the primary goal of breeding programs. However, in forage crops, in which the vegetative parts of plants are the major agronomic focus, efforts to increase seed yield are still neglected.

The success of new forage materials depends on their ability to produce dry matter, nutritional quality, palatability, yield stability, pest and disease resistance, and high capacity to produce viable seeds (Batista and Godoy, 1998). Although Paspalum species have shown promising results in terms of forage production, their commercial success is limited by the lack of public incentive policies and scarcity of research on management techniques and quality seed production (Lopes and Franke, 2011a).

The objective of this study was to determine the genetic variability and expression of seed yield components in 23 apomictic Paspalum plicatulum $\times$ Paspalum lepton hybrids and two male parent plants (P. lepton), aimed at improving 
prospects for genetic advances in the Paspalum breeding program.

\section{Material and Methods}

The experiment was conducted in the 2013/2014 and 2014/2015 growing seasons in Eldorado do Sul (Rio Grande do Sul, Brazil), located in the Central Depression region $\left(30^{\circ} 05^{\prime} 52^{\prime \prime} \mathrm{S}\right.$ and $51^{\circ} 39^{\prime} 08^{\prime \prime} \mathrm{W}$, at an altitude of $32 \mathrm{~m}$ ). The climate is type Cfa, according to the Köppen classification system, with annual rainfall of $1440 \mathrm{~mm}$ (monthly average of $120 \mathrm{~mm}$ ). The soil is dystrophic Argisoil (Rhodustults - PVd) (Embrapa, 2013), with the following chemical characteristics: $\mathrm{pH}\left(\mathrm{H}_{2} \mathrm{O}\right), 5.6$; SMP index, 6.1; $\mathrm{P}, 4.5 \mathrm{mg} \mathrm{dm}^{-3}$; $\mathrm{K}, 80 \mathrm{mg} \mathrm{dm}^{-3}$; organic matter, $1.2 \% ; \mathrm{Al}^{3+}, 0.0 \mathrm{cmol} \mathrm{dm}{ }^{-3} ; \mathrm{Ca}^{2+}, 2.9$ cmolc dm${ }^{-3} ; \mathrm{Mg}^{2+}, 1.4$ cmolc dm${ }^{-3}$; and cation exchange capacity, $8.4 \mathrm{cmolc} \mathrm{dm}^{-3}$. The experimental area $\left(11.0 \times 28.0 \mathrm{~m}=308.0 \mathrm{~m}^{2}\right)$ was corrected with $2215 \mathrm{~kg} \mathrm{ha}^{-1}$ of lime on July 7, 2013 and in October 2013 , with $250.0 \mathrm{~kg} \mathrm{ha}^{-1}$ of 5-20-20 fertilizer, satisfying the demand for potassium. This recommended amount was supplemented with $100.0 \mathrm{~kg} \mathrm{ha}^{-1}$ of $\mathrm{N}$ (urea) and 125.5 $\mathrm{kg} \mathrm{ha}^{-1}$ of $\mathrm{P}_{2} \mathrm{O}_{5}$ (triple superphosphate), meeting the needs of perennial warm-season grasses (CQFS-RS/SC, 2004). In the second year, $25.0 \mathrm{~kg} \mathrm{ha}^{-1}$ of $\mathrm{N}$ (urea) and $65.0 \mathrm{~kg} \mathrm{ha}^{-1}$ of $\mathrm{P}_{2} \mathrm{O}_{5}$ (replenishment dose) were applied.

Seedlings were kept in a greenhouse during the winter until the time for planting in the field (October 24, 2013). The twenty-five apomictic genotypes assessed (23 P. plicatulum $\times$ P. lepton + two P. lepton) belong to the Department of Forage Plants and Agrometeorology/UFRGS (Pereira, 2013). In the second year, rejuvenation pruning was performed on all the genotypes (September 26, 2014), leaving $0.15 \mathrm{~m}$ of residue.

All inflorescences per plant were harvested when more than $50 \%$ exhibited brown coloring and signs of dehiscence in caryopsis (March 25, 2014 - first year - and February 18, 2015 - second year). Prior to harvesting, the following components were assessed: number of total tillers (TT) direct count of all the tillers/plant; vegetative tillers/plant (VT) - direct count of tillers in a vegetative phase/plant; reproductive tillers/plant (RT) - direct count of the tillers that formed inflorescences; percentage of reproductive tillers in relation to the total tillers/plant (PRT) - percentage between RT and TT; and number of racemes/inflorescence (NRI) - average number of racemes of six inflorescences from each plant, randomly chosen for each genotype.

The following analyses were conducted after seed harvesting: seed yield/plant (SY) - the inflorescences collected were dried in a forced-air oven at $30^{\circ} \mathrm{C}$ for $72 \mathrm{~h}$ and manually threshed. Sieves were used to remove impurities and a South Dakota blower to separate heavy and empty seeds. After cleaning, the pure seeds of each genotype were weighed, expressed in g; weight of a thousand seeds (WTS) - average weight of eight subsamples of 100 seeds, multiplied by 10 (Brasil, 2009); and number of seeds/inflorescence (NSI) rule of three between WTS and the average weight of seeds per inflorescence. The average weight of seeds/inflorescence was determined at harvest, when five intact inflorescences were separated from each genotype, manually threshed, processed, and individually weighed on a precision scale (average of five inflorescences, expressed in g).

A randomized block design was used, with genotypes individually arranged into ten blocks. The experiment was composed of 250 experimental units ( 250 plants with intra and inter-row spacing of $1.0 \mathrm{~m}$ ), corresponding to the 25 genotypes, with ten repetitions. The data were statistically interpreted by analysis of variance and, in the event of a significant difference, means were compared using the Scott-Knott test at 5\% probability. Multivariate analysis was applied, with generalized Mahalanobis distance $\left(\mathrm{D}^{2}\right)$. Clustering was performed using the eight variables studied. Next, eight successive clusterings were performed using Tocher's optimization method, eliminating the variables that did not affect the original cluster. The magnitude of the relative contribution of the variables $(S . j)$, for the total variability observed, was determined by Singh's model (Singh, 1981). Data were analyzed using the Genes program (Cruz, 2013).

\section{Results and Discussion}

Significant differences were observed in all seed yield components for both factors (genotype and year) and in interaction between the factors (Table 1). Pereira et al. (2011) studied varieties of P. lepton and also found a significant effect in genotype $\times$ year interaction, demonstrating the variations in these varieties over the assessment years. The identification of genotypes with greater phenotypic stability is a widely used alternative to minimize the effects of genotype interaction with the environment and make the process of identifying forage plants safer (Melo et al., 2007).

The year was the factor that most influenced the expression of variability in total tillers, vegetative tillers, reproductive tillers, percentage of reproductive tillers in relation to total tillers, and seed yield, indicated by the high mean square values (Table 1). Other studies have demonstrated the importance of analyzing perennial warmseason grasses over several years (Pereira et al., 2012). 
By contrast, the number of racemes/inflorescence, number of seeds/inflorescence, and weight of a thousand seeds indicated that genotype had a greater effect on changes in these variables. Total tillers, reproductive tillers, and number of seeds/inflorescence were significantly influenced by the interaction between genotypes and growing seasons studied (years) and were, therefore, most effective at identifying superior genotypes. The coefficient of variation ranged between 3.3 and $21.0 \%$, indicating good consistency for experimental data (Table 1).

The highest mean TT values were recorded in the second year of assessment, with the exception of genotype 10E4039, which did not exhibit significance $(\mathrm{P}<0.05)$ (Table 2$)$. In the first year, four distinct groups were observed in relation

Table 1 - Summary of analysis of variance for the components of seed yield in interspecific Paspalum hybrids

\begin{tabular}{|c|c|c|c|c|c|c|c|c|c|}
\hline \multirow{2}{*}{ Source of variability } & \multirow{2}{*}{ DF } & \multicolumn{8}{|c|}{ Mean square } \\
\hline & & $\mathrm{TT}$ & VT & RT & PRT & NRI & NSI & WTS & SY \\
\hline Block & 9 & 478.7 & 295.3 & 210.5 & 59.8 & 0.3 & 82.2 & 0.1 & 3.2 \\
\hline Genotype (G) & 24 & $6781.5^{* *}$ & $1927.0 * *$ & $6323.7 * *$ & $518.6 * *$ & $11.80 * *$ & $63917.7 * *$ & $10.4 * *$ & $10506.2 * *$ \\
\hline Year (Y) & 1 & $371881.0 * *$ & $70995.5 * *$ & $117903.4 * *$ & $5223.6 * *$ & $9.2 * *$ & $25049.0 * *$ & $0.2 *$ & $194526.0 * *$ \\
\hline $\mathrm{G} \times \mathrm{Y}$ & 24 & $5780.7 * *$ & $1766.1 * *$ & $5076.5^{* *}$ & $454.7 * *$ & $7.2 * *$ & $5799.7 * *$ & $0.5 * *$ & $5388.4 * *$ \\
\hline Error & 441 & 161.7 & 18797.6 & 123.3 & 13.5 & 0.3 & 124.8 & 0.1 & 7.9 \\
\hline Total & 499 & - & - & - & - & - & - & - & - \\
\hline Means & & 159.2 & 39.4 & 119.8 & 75.6 & 5.8 & 177.3 & 3.5 & 59.2 \\
\hline $\mathrm{CV}(\%)$ & & 8.0 & 21.0 & 9.3 & 4.9 & 8.7 & 6.3 & 3.3 & 4.7 \\
\hline
\end{tabular}

DF - degrees of freedom; TT - total tillers; VT - vegetative tillers; RT - reproductive tillers; PRT - percentage of reproductive tillers; NRI - number of racemes per inflorescence; NSI - number of seeds per inflorescence; WTS - weight of thousand seeds; SY - seed yield; CV - coefficient of variation.

* Significant at $5 \%$ of probability, by F-Test.

** Significant at $1 \%$ of probability, by F-Test.

Table 2 - Means of the total number of tillers, vegetative tillers, reproductive tillers, and percentage of reproductive tillers in relation to total tillers of interspecific Paspalum hybrids

\begin{tabular}{|c|c|c|c|c|c|c|c|c|}
\hline \multirow{3}{*}{ Genotype } & \multicolumn{8}{|c|}{ Seed yield component } \\
\hline & \multicolumn{2}{|c|}{$\begin{array}{c}\text { Total tillers } \\
\text { (number.plant }^{-1} \text { ) }\end{array}$} & \multicolumn{2}{|c|}{$\begin{array}{l}\text { Vegetative tillers } \\
\text { (number.plant }^{-1} \text { ) }\end{array}$} & \multicolumn{2}{|c|}{$\begin{array}{l}\text { Reproductive tillers } \\
\text { (number.plant }^{-1} \text { ) }\end{array}$} & \multicolumn{2}{|c|}{$\begin{array}{l}\text { Percentage of reproductive tillers } \\
\text { in relation to total tillers } \\
\text { (number.plant }^{-1} \text { ) }\end{array}$} \\
\hline & $2013 / 2014$ & $2014 / 2015$ & $2013 / 2014$ & $2014 / 2015$ & $2013 / 2014$ & $2014 / 2015$ & $2013 / 2014$ & $2014 / 2015$ \\
\hline 10E6086 & B130.8c & A204.7c & B32.2b & A51.7e & B98.6d & $\mathrm{A} 153.0 \mathrm{c}$ & A75.1c & A75.1d \\
\hline $10 \mathrm{E} 5052$ & B $114.4 d$ & $\mathrm{~A} 273.8 \mathrm{a}$ & B32.5b & A $55.7 \mathrm{e}$ & B81.9f & A218.1a & B71.6d & $\mathrm{A} 79.7 \mathrm{c}$ \\
\hline $10 \mathrm{E} 4071$ & B119.4d & $\mathrm{A} 167.9 \mathrm{e}$ & B29.1c & A36.5g & B90.3e & $\mathrm{A} 131.4 \mathrm{e}$ & A75.6c & $\mathrm{A} 78.2 \mathrm{c}$ \\
\hline $10 \mathrm{E} 5023$ & B153.3a & A166.0e & A29.1c & A $29.2 \mathrm{~h}$ & $\mathrm{~B} 124.2 \mathrm{~b}$ & A136.8e & $\mathrm{A} 81.0 \mathrm{~b}$ & $\mathrm{~A} 82.4 \mathrm{~b}$ \\
\hline $10 \mathrm{E} 4026$ & $\mathrm{~B} 158.0 \mathrm{a}$ & $\mathrm{A} 192.0 \mathrm{c}$ & B35.7b & $\mathrm{A} 52.9 \mathrm{e}$ & B122.3b & A139.1e & A77.5c & B72.6d \\
\hline $10 \mathrm{E} 507$ & $\mathrm{~B} 135.6 \mathrm{c}$ & A199.6c & $\mathrm{B} 23.5 \mathrm{c}$ & $\mathrm{A} 42.2 \mathrm{f}$ & $\mathrm{B} 112.1 \mathrm{c}$ & $\mathrm{A} 157.4 \mathrm{c}$ & A $82.7 \mathrm{a}$ & B78.9c \\
\hline $10 \mathrm{E} 4025$ & $\mathrm{~B} 133.8 \mathrm{c}$ & A186.5d & $\mathrm{A} 23.0 \mathrm{c}$ & A18.3i & $\mathrm{B} 110.8 \mathrm{c}$ & $\mathrm{A} 168.2 \mathrm{~b}$ & $\mathrm{~B} 82.7 \mathrm{a}$ & A90.2a \\
\hline 10E40104 & $\mathrm{B} 161.3 \mathrm{a}$ & $\mathrm{A} 201.5 \mathrm{c}$ & B26.6c & A39.2g & B134.7a & A162.3b & A83.4a & $\mathrm{A} 80.5 \mathrm{~b}$ \\
\hline 10E6084 & B116.0d & A176.8d & A26.3c & $\mathrm{A} 30.2 \mathrm{~h}$ & B89.7e & A146.6d & B74.0d & $\mathrm{A} 83.0 \mathrm{~b}$ \\
\hline 10E6069 & B111.3d & A201.5c & B23.7c & A35.3g & B87.6e & A166.2b & B78.7b & A82.6b \\
\hline $10 \mathrm{E} 4076$ & B133.1c & A184.4d & B23.7c & A41.5f & B109.4c & $\mathrm{A} 142.9 \mathrm{~d}$ & A82.1a & B77.5c \\
\hline $10 \mathrm{E} 4077$ & B103.3d & $\mathrm{A} 153.2 \mathrm{e}$ & B26.2c & $\mathrm{A} 48.3 \mathrm{e}$ & B77.1f & A104.9h & A74.7c & B68.5e \\
\hline 10E5017 & B154.0a & A196.2c & B24.1c & A $49.5 \mathrm{e}$ & B129.9a & $\mathrm{A} 146.7 \mathrm{~d}$ & A84.3a & B74.8d \\
\hline 10E6024 & $\mathrm{B} 125.2 \mathrm{c}$ & A182.0d & B24.5c & A45.1f & $\mathrm{B} 100.7 \mathrm{~d}$ & A136.9e & $\mathrm{A} 80.3 \mathrm{~b}$ & B75.4d \\
\hline 10E6088 & $\mathrm{B} 141.2 \mathrm{~b}$ & $\mathrm{~A} 211.7 \mathrm{c}$ & B24.8c & A71.1c & B $116.4 \mathrm{c}$ & A $140.6 d$ & A $82.4 a$ & B66.5e \\
\hline 10E6022 & $\mathrm{B} 131.4 \mathrm{c}$ & $\mathrm{A} 160.8 \mathrm{e}$ & B26.0c & A36.0g & $\mathrm{B} 105.4 \mathrm{c}$ & A124.8f & $\mathrm{A} 80.2 \mathrm{~b}$ & A77.6c \\
\hline 10E4099 & $\mathrm{B} 124.3 \mathrm{c}$ & A181.0d & B22.7c & A86.2b & A101.6d & A94.8h & A81.7a & B52.4g \\
\hline $10 \mathrm{E} 4087$ & B110.7d & A176.3d & B26.6c & A66.1d & B88.1e & $\mathrm{A} 110.2 \mathrm{~g}$ & A79.6b & B62.7f \\
\hline $10 \mathrm{E} 40177$ & B106.4d & A158.6e & B26.0c & A63.4d & B80.4f & A95.2h & A75.5c & B60.3f \\
\hline 10E50150 & $\mathrm{B} 122.4 \mathrm{c}$ & A249.3b & $\mathrm{B} 27.0 \mathrm{c}$ & A103.3a & B95.4d & A146.0d & A78.0c & B58.5f \\
\hline $10 \mathrm{E} 4039$ & A $135.6 \mathrm{c}$ & $\mathrm{A} 128.0 \mathrm{~g}$ & B29.8c & A49.1e & $\mathrm{A} 105.8 \mathrm{c}$ & B78.9i & A78.1c & B61.3f \\
\hline $10 \mathrm{E} 6058$ & B113.0d & A145.8f & B25.3c & A45.8f & B87.7e & A100.0h & A77.6c & B68.7e \\
\hline $10 \mathrm{E} 6047$ & B159.8a & $\mathrm{A} 196.0 \mathrm{c}$ & $\mathrm{B} 27.4 \mathrm{c}$ & A62.3d & $\mathrm{A} 132.4 \mathrm{a}$ & $\mathrm{A} 133.7 \mathrm{e}$ & A $82.7 a$ & B68.4e \\
\hline $28 \mathrm{~B}$ & B140.2b & $\mathrm{A} 187.2 \mathrm{~d}$ & B28.7c & A64.6d & B111.5c & A122.6f & A79.0b & B65.8e \\
\hline $28 \mathrm{E}$ & B164.2a & A181.5d & B46.8a & A59.6d & A117.4c & A121.9f & $\mathrm{A} 71.5 \mathrm{~d}$ & B66.9e \\
\hline Means & 131.9 & 186.5 & 27.5 & 51.3 & 104.5 & 135.2 & 78.8 & 72.3 \\
\hline CV (\%) & 8.9 & 7.2 & 11.2 & 16.4 & 10.6 & 7.9 & 4.8 & 4.6 \\
\hline
\end{tabular}

$\mathrm{CV}$ - coefficient of variation.

Values followed by the same lowercase letter in columns and uppercase in rows do not differ by the Scott-Knott test at $5 \%$ probability. 
to TT. The genotypes with the highest TT values that year were 28E, 10E40104, 10E6047, 10E4026, 10E5017, and 10E5023. The second year showed greater expression of variability in the formation of seven statistically different classes, with better performance of genotype 10E5052 and poor performance of 10E4039. Kuraparthy et al. (2007) questioned the use of number of tillers in terms of its best application in different species, due to the complexity of genetic control and the processes involved in its phenotypic expression, as well as the different responses to soil and climate conditions and management systems.

With respect to VT, similar results were observed to those recorded for TT in terms of significant differences between assessment years, particularly for the $28 \mathrm{E}$ and 10E50150 varieties (Table 2). No significant differences $(\mathrm{P}<0.05)$ were observed between the years for genotypes 10E5023, 10E4025, and 10E6084. Once again, the second year showed greater variability, with the formation of nine statistically significant classes, with the best performance observed in genotype 10E50150 and the worst in genotype 10E4025. According to Moore et al. (2004), tiller populations in established pastures adjust to the constraints imposed by the genotype in response to stimulants resulting from climate variations and the level of competition between them.

In tests to compare means for the variable RT (Table 2), variability was recorded in the first year (2013/2014), with six distinct classes and the highest variability observed for genotypes 10E40104, 10E6047, and 10E5017. In $2014 / 2015$, the year of perennialization, a difference was observed in the expression of RT, with genotype 10E5052 exhibiting the highest expression for this variable. Analysis of the results between years indicated that plants exhibited the highest values in the second year. However, there were no significant differences $(\mathrm{P}<0.05)$ in 10E4099, 10E6047, and 28E, and genotype 10E4039 showed the highest values in the first year. The reference section indicates RT as one of the most important components to achieve satisfactory seed production in forage grasses (Lopes and Franke, 2011a,b), also serving as an indicator for breeding programs aimed at improving the seed production of forage species (Biligetu et al., 2013).

The main effects (genotype and years) and their interaction (genotypes $\times$ years), significantly influenced $(\mathrm{P}<0.05)$ the percentage of reproductive tillers in relation to total tillers (Table 2). Analysis of this variable expresses the rate of tillers that progressed into the reproductive phase in relation to the total number of tillers produced by the plant. Differences were recorded between the years assessed, with superior results observed for the first year. The expression of variability was most evident in the second year, with the formation of six phenotypic classes and the highest results recorded for genotype 10E4025. According to Lopes and Franke (2011a), the percentage of fertile tillers is influenced by the ratio between vegetative tillers and those that produced inflorescences. Thus, the greater the number of reproductive (flowering) tillers in relation to vegetative tillers, the higher the fertility rates.

The high expression of total tillers, vegetative tillers, and reproductive tillers recorded in the second year, combined with better detection of variability (Table 2), suggests that promising genotypes should not be selected based on the first year of assessment. In perennial species, the year of planting is a period of adaptation in relation to initial establishment (Pereira et al., 2015). In subsequent years, after perennialization, photoassimilates are targeted towards the expression of agronomic traits, making it easier to identify the differences between genotypes (Pereira et al., 2011).

Analysis of variance of the number of racemes/ inflorescence revealed significance $(\mathrm{P}<0.05)$ in genotype $\times$ years interaction and in the isolated effects of genotypes and years (Table 3). Differences were observed in the years studied, with higher values in the second year. The expression of variability was the same between the years, with the formation of six phenotypic classes and the highest results for genotype 10E4026. It is important to underscore that $P$. lepton (male parent) has 2-5 racemes/inflorescence and $P$. plicatulum (female parent) has 3-7 racemes/ inflorescence (Wunderlin et al., 2016), likely contributing to the diversity of this variable after hybridization.

Interaction between genotypes and years was significant $(\mathrm{P}<0.05)$ for the variable NSI, demonstrating different behavior for the genotypes in different environments (Table 3). In the first year, nine distinct classes were observed in relation to TT, with the highest value recorded for genotype 10E5052. The second year showed greater expression of variability with the formation of ten statistically distinct classes and genotype 10E5052 once again was found to be the most prominent. Male parents 28B and 28E (P. lepton) exhibited the lowest NSI in both years. Analysis of the means of components NRI and NSI (Table 3 ) between the years showed that an increase in one led to a decrease in the other, given the plant plasticity or compensation ability (Nakagawa, 2014).

A significant effect $(\mathrm{P}<0.05)$ was observed in genotype $\times$ year interaction and the isolated effects of genotypes and years for WTS, making it easier to identify the differences between genotypes (Table 3). Expression of variability was similar between years, with the formation of 12 
phenotypic classes in year 1 and 13 in year 2. Genotype 10E4077 showed superior WTS in both years. In the second year, genotype 10E6088 did not differ statistically from 10E4077 (Table 3). Evidence suggests that seed size plays an important role in regulating genetic control of the number of seeds produced (Sadras, 2007).

Both main effects (genotypes and years) and interaction between the factors (genotypes $\times$ years) significantly influenced $(\mathrm{P}<00.5)$ seed yield (SY) (Table 3). Seed yield was higher in the second year, with the exception of genotype 10E4039 and the male parent plants $(28 \mathrm{~B}$ and $28 \mathrm{E}$ ), which did not differ significantly between years. The first year saw the formation of eight phenotypic classes, while 16 statistically different classes were observed in the second year, demonstrating greater expression of variability. Differences in SY between the years may be associated with the adaptation of plants following transplantation, which culminated in better development and production after perennialization (second year). According to Souza (2001), in the first year of cultivation, perennial grasses exhibit lower yields due to the delayed onset of the reproductive phase, indicating the existence of a juvenile period, when plants need a certain level of growth before flowering.

In forage grass species such as Paspalum, a large portion of the components linked to seed yield are related to inflorescence (NRI, NSI, and WTS) and its reproductive and fertile tillers (RT and PRT) (Lopes and Franke, 2011a,b). As such, more conclusive gains in the selection pressure for seed yield can be obtained by studying these characteristics. According to Carvalho et al. (2008), this technique favors the selection of high performance genotypes through indirect selection of characteristics that are difficult to choose and measure, such as seed yield.

Genetic dissimilarity measurements, estimated based on the Mahalanobis distance $\left(\mathrm{D}^{2}\right)$, showed a high magnitude (1.246 to 476.561 ), indicating significant genetic variability between genotypes (Table 4).

The combination between genotype 10E4077 and 28E was the most divergent $\left(D^{2}=476.561\right)$, followed by the pair $10 \mathrm{E} 4077$ and 28B $\left(\mathrm{D}^{2}=461.086\right)$. The shortest distance was obtained between genotypes $28 \mathrm{~B}$ and $28 \mathrm{E}\left(\mathrm{D}^{2}=1.246\right)$, followed by $10 \mathrm{E} 4099$ and $10 \mathrm{E} 4087\left(\mathrm{D}^{2}=1.409\right), 10 \mathrm{E} 5017$

Table 3 - Means of the number of racemes per inflorescence, number of seeds per inflorescence, weight of a thousand seeds, and seed yield of inter specific Paspalum hybrids

\begin{tabular}{|c|c|c|c|c|c|c|c|c|}
\hline \multirow{3}{*}{ Genotype } & \multicolumn{8}{|c|}{ Seed yield component } \\
\hline & \multicolumn{2}{|c|}{$\begin{array}{c}\text { Number of racemes per inflorescence } \\
\left.\text { (number.inflorescence }{ }^{-1}\right)\end{array}$} & \multicolumn{2}{|c|}{$\begin{array}{l}\text { Number of seeds per inflorescence } \\
\left.\text { (number.inflorescence }{ }^{-1}\right)\end{array}$} & \multicolumn{2}{|c|}{$\begin{array}{l}\text { Weight of a thousand seeds } \\
\qquad(\mathrm{g})\end{array}$} & \multicolumn{2}{|c|}{$\begin{array}{l}\text { Seed yield } \\
\left(\text { g.plant }{ }^{-1}\right)\end{array}$} \\
\hline & $2013 / 2014$ & $2014 / 2015$ & $2013 / 2014$ & $2014 / 2015$ & $2013 / 2014$ & $2014 / 2015$ & $2013 / 2014$ & $2014 / 2015$ \\
\hline 10E6086 & A5.7d & A $5.4 \mathrm{e}$ & B184.9f & $\mathrm{A} 221.8 \mathrm{c}$ & A3.67f & B3.18j & B47.3c & A106.0d \\
\hline $10 \mathrm{E} 5052$ & B5.7d & A6.3c & A $321.4 a$ & B254.9a & B2.70k & A $2.90 \mathrm{k}$ & B39.1d & A141.1a \\
\hline 10E4071 & $\mathrm{B} 4.8 \mathrm{e}$ & A $5.3 \mathrm{e}$ & $\mathrm{A} 255.1 \mathrm{c}$ & B239.6b & B3.54g & A3.82f & B47.5c & A139.9a \\
\hline 10E5023 & A $5.5 d$ & A $5.2 \mathrm{e}$ & A179.4f & B124.8h & A3.72f & B3.37i & B40.6d & A50.71 \\
\hline $10 \mathrm{E} 4026$ & A7.3a & A7.5a & $\mathrm{A} 278.1 \mathrm{~b}$ & B211.1c & B3.46g & A3.66g & B52.5b & $\mathrm{A} 121.4 \mathrm{~b}$ \\
\hline 10E507 & A6.7b & B5.6d & B197.9e & $\mathrm{A} 212.3 \mathrm{c}$ & B3.73f & $\mathrm{A} 4.09 \mathrm{~d}$ & B $46.0 \mathrm{c}$ & $\mathrm{A} 121.0 \mathrm{~b}$ \\
\hline $10 \mathrm{E} 4025$ & A5.8d & A $5.7 d$ & A198.4e & B185.0e & A3.69f & A3.79f & B48.3c & $\mathrm{A} 117.3 \mathrm{c}$ \\
\hline 10E40104 & B5.0e & A $5.5 d$ & $\mathrm{~B} 172.4 \mathrm{~g}$ & A $215.1 \mathrm{c}$ & $\mathrm{A} 4.07 \mathrm{~d}$ & B3.74g & B29.9g & $\mathrm{A} 120.2 \mathrm{~b}$ \\
\hline 10E6084 & A6.0c & A5.8d & A181.7f & A175.4f & A4.19c & B3.92e & B $48.7 \mathrm{c}$ & $\mathrm{A} 82.9 \mathrm{~h}$ \\
\hline 10E6069 & A6.6b & B5.3e & A183.0f & $\mathrm{B} 111.2 \mathrm{i}$ & $\mathrm{A} 3.49 \mathrm{~g}$ & B3.33i & B36.5e & $\mathrm{A} 45.5 \mathrm{~m}$ \\
\hline $10 \mathrm{E} 4076$ & B5.7d & $\mathrm{A} 6.7 \mathrm{~b}$ & A191.7e & A186.3e & B3.36h & A $3.50 \mathrm{~h}$ & $\mathrm{~B} 27.5 \mathrm{~g}$ & A90.5g \\
\hline 10E4077 & B5.0e & A7.4a & $\mathrm{B} 169.8 \mathrm{~g}$ & A196.6d & A4.79a & B4.58a & B40.2d & $\mathrm{A} 100.3 \mathrm{e}$ \\
\hline 10E5017 & B5.0e & A6.3c & $\mathrm{A} 170.6 \mathrm{~g}$ & A168.1f & $\mathrm{A} 3.83 \mathrm{e}$ & B3.72g & $\mathrm{B} 47.2 \mathrm{c}$ & A94.2f \\
\hline 10E6024 & B5.0e & A7.6a & A $244.9 d$ & B229.7b & B2.77k & A $3.16 j$ & B $42.4 d$ & A74.7i \\
\hline 10E6088 & A6.5b & A6.8b & A $160.9 \mathrm{~h}$ & A163.8f & B4.16c & $\mathrm{A} 4.48 \mathrm{a}$ & B39.9d & A84.5h \\
\hline 10E6022 & $\mathrm{B} 4.9 \mathrm{e}$ & A $5.7 d$ & B163.6h & A195.3d & A3.70f & A3.68g & B36.2e & $\mathrm{A} 89.2 \mathrm{~g}$ \\
\hline 10E4099 & A $5.7 d$ & A5.3e & B182.1f & A207.1c & A3.39h & $\mathrm{A} 3.40 \mathrm{i}$ & B34.1f & A $54.8 \mathrm{k}$ \\
\hline $10 \mathrm{E} 4087$ & B5.0e & A6.1c & A188.6f & B172.0f & B3.37h & A3.62h & B $46.0 \mathrm{c}$ & A $53.4 \mathrm{k}$ \\
\hline $10 \mathrm{E} 40177$ & B5.0e & A6.6b & A161.0h & B128.5h & A $4.57 b$ & $\mathrm{~B} 4.37 \mathrm{~b}$ & A41.3d & $\mathrm{A} 42.3 \mathrm{n}$ \\
\hline $10 \mathrm{E} 50150$ & B5.0e & A7.1a & A194.6e & B148.1g & $\mathrm{B} 3.00 \mathrm{j}$ & A3.30i & B36.4e & A66.3j \\
\hline 10E4039 & $\mathrm{A} 7.4 \mathrm{a}$ & B6.5b & A196.7e & B133.1h & B3.23i & $\mathrm{A} 4.21 \mathrm{c}$ & A67.9a & B54.9k \\
\hline 10E6058 & A6.7b & A6.6b & A185.8f & $\mathrm{B} 146.8 \mathrm{~g}$ & $\mathrm{~A} 2.94 \mathrm{j}$ & A2.96k & B33.6f & A37.7o \\
\hline $10 \mathrm{E} 6047$ & A6.5b & B6.0c & $\mathrm{A} 192.0 \mathrm{e}$ & B176.8f & $\mathrm{A} 3.92 \mathrm{e}$ & B3.56h & B50.6b & A73.5i \\
\hline $28 \mathrm{~B}$ & A5.6d & B3.0g & A28.9i & $\mathrm{A} 23.6 \mathrm{j}$ & A1.601 & A1.621 & A4 $4.2 \mathrm{~h}$ & A5.6p \\
\hline $28 \mathrm{E}$ & A4.0f & A3.6f & A24.7i & $\mathrm{A} 27.3 \mathrm{j}$ & A1.601 & $\mathrm{B} 1.51$ & A3.7h & A5.7p \\
\hline Means & 5.7 & 6.0 & 184.3 & 170.2 & 3.46 & 3.49 & 39.5 & 78.9 \\
\hline CV (\%) & 7.4 & 9.7 & 4.2 & 8.1 & 3.0 & 3.6 & 7.3 & 3.5 \\
\hline
\end{tabular}

$\mathrm{CV}$ - coefficient of variation.

Values followed by the same lowercase letter in columns and uppercase in rows do not differ by the Scott-Knott test at $5 \%$ probability. 
and 10E6047 $\left(\mathrm{D}^{2}=1.415\right)$, and 10E5023 and 10E6069 $\left(\mathrm{D}^{2}=1.571\right)$. The maximum $\mathrm{D}^{2}$ distance between all the possible combinations of each genotype assessed was obtained for pairs with $28 \mathrm{E}$, indicating this genotype as the most divergent of those studied. The shortest distances measured between pairs $28 \mathrm{~B}$ and $28 \mathrm{E}\left(\mathrm{D}^{2}=1.246\right)$ occurred because the genotypes were the male parent plants, two species of P. lepton. Knowledge of genetic dissimilarity within a species is vital, primarily in the characterization of genotypes and as a selection criterion for parent plants in programs involving crossbreeding. Its importance is related to the need to identify genitors that, in future crossbreeding, will enable greater heterosis in progeny and wider genetic variability in segregating populations, thus increasing the likelihood of obtaining superior individuals (Carvalho et al., 2008).

Clustering analysis using Tocher's method separated twenty-five genotypes into six groups (Table 5).

Groups I, IV, V, and VI were formed by two genotypes, representing $8.0 \%$ (each group) of the total studied. Group II contained 14 genetically similar genotypes $(56.0 \%$ of the total genotypes), indicating that possible crossbreeding between these genotypes would decrease the likelihood of obtaining superior genotypes. Group III consisted of three genotypes,

Table 4 - Estimated Mahalanobis distances (D2), based on five components of seed yield ${ }^{1}$, in interspecific Paspalum hybrids

\begin{tabular}{|c|c|c|c|c|c|}
\hline Genotype & Largest $\mathrm{D}^{2}$ & $\begin{array}{l}\text { Most distant } \\
\text { genotype }\end{array}$ & Smallest $\mathrm{D}^{2}$ & $\begin{array}{c}\text { Closest } \\
\text { genotype }\end{array}$ & Mean $\mathrm{D}^{2}$ \\
\hline 10E6086 & 270.158 & $28 \mathrm{E}$ & 2.576 & $10 \mathrm{E} 4076$ & 34.061 \\
\hline $10 \mathrm{E} 5052$ & 321.140 & $28 \mathrm{E}$ & 14.195 & 10E6024 & 72.479 \\
\hline $10 \mathrm{E} 4071$ & 383.161 & $28 \mathrm{E}$ & 7.699 & 10E507 & 52.741 \\
\hline $10 \mathrm{E} 5023$ & 233.305 & $28 \mathrm{E}$ & 1.571 & 10E6069 & 34.364 \\
\hline $10 \mathrm{E} 4026$ & 363.876 & $28 \mathrm{E}$ & 8.601 & 10E507 & 50.025 \\
\hline $10 \mathrm{E} 507$ & 365.494 & $28 \mathrm{E}$ & 2.204 & $10 \mathrm{E} 40104$ & 44.624 \\
\hline $10 \mathrm{E} 4025$ & 326.146 & $28 \mathrm{E}$ & 2.637 & $10 \mathrm{E} 507$ & 40.272 \\
\hline $10 \mathrm{E} 40104$ & 348.232 & $28 \mathrm{E}$ & 2.204 & $10 \mathrm{E} 507$ & 44.468 \\
\hline 10E6084 & 349.219 & $28 \mathrm{E}$ & 2.891 & $10 \mathrm{E} 507$ & 43.438 \\
\hline 10E6069 & 208.695 & $28 \mathrm{E}$ & 2.576 & $10 \mathrm{E} 6086$ & 35.479 \\
\hline $10 \mathrm{E} 4076$ & 261.414 & $28 \mathrm{E}$ & 2.576 & 10E6086 & 32.831 \\
\hline $10 \mathrm{E} 4077$ & 476.561 & $28 \mathrm{E}$ & 8.448 & $10 \mathrm{E} 40177$ & 80.196 \\
\hline $10 \mathrm{E} 5017$ & 287.706 & $28 \mathrm{E}$ & 1.415 & $10 \mathrm{E} 6047$ & 35.335 \\
\hline 10E6024 & 260.535 & $28 \mathrm{E}$ & 7.526 & $10 \mathrm{E} 6086$ & 43.675 \\
\hline 10E6088 & 373.198 & $28 \mathrm{E}$ & 4.084 & 10E6084 & 52.432 \\
\hline 10E6022 & 286.079 & $28 \mathrm{E}$ & 2.386 & $10 \mathrm{E} 5017$ & 34.802 \\
\hline $10 \mathrm{E} 4099$ & 244.386 & $28 \mathrm{E}$ & 1.409 & $10 \mathrm{E} 4087$ & 34.782 \\
\hline $10 \mathrm{E} 4087$ & 246.004 & $28 \mathrm{E}$ & 1.409 & $10 \mathrm{E} 4099$ & 32.934 \\
\hline 10E40177 & 369.705 & $28 \mathrm{E}$ & 6.735 & 10E6088 & 59.886 \\
\hline $10 \mathrm{E} 50150$ & 185.735 & $28 \mathrm{E}$ & 6.567 & $10 \mathrm{E} 4099$ & 39.458 \\
\hline $10 \mathrm{E} 4039$ & 268.257 & $28 \mathrm{E}$ & 4.981 & $10 \mathrm{E} 4087$ & 37.703 \\
\hline $10 \mathrm{E} 6058$ & 167.789 & $28 \mathrm{E}$ & 9.137 & 10E50150 & 46.926 \\
\hline $10 \mathrm{E} 6047$ & 297.617 & $28 \mathrm{E}$ & 1.415 & $10 \mathrm{E} 5017$ & 35.301 \\
\hline $28 \mathrm{~B}$ & 461.086 & $10 \mathrm{E} 4077$ & 1.246 & $28 \mathrm{E}$ & 276.542 \\
\hline $28 \mathrm{E}$ & 476.561 & 10E4077 & 1.246 & $28 \mathrm{~B}$ & 287.319 \\
\hline
\end{tabular}

${ }^{1}$ Reproductive tillers, percentage of reproductive tillers, number of racemes per inflorescence, number of seeds per inflorescence, and weight of thousand seeds. demonstrating that $12.0 \%$ of the genotypes were in the same group. The formation of these groups is essential to the selection of parent plants, since new hybrid combinations to be established should be based on the magnitude of their dissimilarities and potential. The genotypes in the most distant groups seem to be dissimilar and can be considered promising in artificial crossbreeding. However, in addition to dissimilarity, parent plants must also exhibit a high mean and variability for the characteristics targeted for improvement (Almeida et al., 2011).

The relative contribution of each variable to genetic variability showed that two components of seed yield contributed to $92.03 \%$ of genetic variability, while three contributed to only $7.97 \%$ (Table 6 ).

Among the variables studied, WTS and NSI were the most efficient at explaining dissimilarity between the genotypes, demonstrating the importance of these variables as a component in yield and possibly the selection of superior genotypes. In general, the remaining quantitative descriptors employed contributed little to explaining the diversity observed between genotypes. Reproductive tillers contributed little to divergence, with $3.07 \%$, despite exhibiting significant variability (77.1 to 218.1 reproductive tillers/plant) (Table 2).

Table 5 - Breakdown of genetic variability through clustering analysis using Tocher's optimization method in interspecific Paspalum hybrids

\begin{tabular}{llc}
\hline Group & \multicolumn{1}{c}{ Genotype } & $\%$ \\
\hline I & 28B 28E & 8.0 \\
II & 10E4099 10E4087 10E6086 10E4076 10E6022 & 56.0 \\
& 10E6047 10E5017 10E5023 10E6069 10E4025 & \\
& 10E4039 10E6084 10E507 10E40104 & \\
III & 10E6088 10E40177 10E4077 & 12.0 \\
IV & 10E50150 10E6058 & 8.0 \\
V & 10E4071 10E4026 & 8.0 \\
VI & 10E5052 10E6024 & 8.0 \\
Total & 25 & 100.0 \\
& Largest distance between the minimums: 14.195 & \\
\hline
\end{tabular}

Table 6 - Relative contribution (S.j) for the variability observed in the components of seed yield, using Singh's method (Singh, 1981) based on the generalized Mahalanobis distance $\left(\mathrm{D}^{2}\right)$ in interspecific Paspalum hybrids

\begin{tabular}{lcc}
\hline Seed yield component & S.j & S.j (\%) \\
\hline Reproductive tillers & 583.235 & 3.07 \\
Percentage of reproductive tillers & 501.196 & 2.64 \\
Number of raceme per inflorescence & 428.770 & 2.26 \\
Number of seeds per inflorescence & 6711.662 & 35.35 \\
Weight of a thousand seeds & 10760.019 & 56.68 \\
\hline
\end{tabular}


Comparison of means combined with clustering analysis using Tocher's method enabled the identification of promising crossbreeding pairs, as well as those that might result in limited variability in segregating populations, such as those between parents of a same group. The most dissimilar genotypes, with distances of high magnitude, may be used in targeted hybridization, increasing the number of desirable recombinations to be used as sources for obtaining superior genotypes for the seed yield of Paspalum.

\section{Conclusions}

The quantification of genetic variability in Paspalum plicatulum $\times$ Paspalum lepton hybrids allow the formation of six groups of genotypes using Tocher's method, with high means for the characteristics studied. Crossbreeding strategies involving genotypes 10E5052 from group VI and 10E4071 from group $\mathrm{V}$ can be undertaken to isolate high yielding segregants, since these genotypes have high seed yielding potential.

\section{Acknowledgments}

To Coordenação de Aperfeiçoamento de Pessoal de Nível Superior (CAPES, case no. 007488/2011-35) for financial support and scholarship granted.

\section{References}

Acuña, C. A.; Blount, A. R.; Quesenberry, K. H.; Kenworthy, K. E. and Hanna, W. W. 2009. Bahiagrass tetraploid germplasm: reproductive and agronomic characterization of segregating progeny. Crop Science 49:581-588.

Almeida, R. D.; Peluzio, J. and Afférri, F. S. 2011. Divergência genética entre cultivares de soja, sob condições de várzea irrigada, no sul do Estado Tocantins. Revista Ciência Agronômica 42:108-115.

Batista, L. A. R. and Godoy, R. 1998. Capacidade de produção de sementes em acessos do gênero Paspalum. Revista Brasileira de Zootecnia 27:841-847.

Biligetu, B.; Schellenberg, M. P.; McLeod, J. G. and Wang, Z. 2013. Seed yield variation in plains rough fescue (Festuca hallii (Vasey) Piper) populations and its relation with phenotypic characteristics and environmental factors. Grass and Forage Science 68:589-595.

Brasil. Ministério da Agricultura, Pecuária e Abastecimento. 2009. Regras para análise de sementes. Secretaria de Defesa Agropecuária, Brasília, DF.

Carvalho, F. I. F.; Lorencetti, C.; Marchioro, V. S. and Silva, S. A. 2008. Condução de populações no melhoramento genético de plantas. UFPel, Pelotas.

CQFS-RS/SC - Comissão de Química e Fertilidade do Solo. 2004. Manual de adubação e de calagem para os estados do Rio Grande do Sul e Santa Catarina. 10.ed. Sociedade Brasileira de Ciência do Solo/Núcleo Regional Sul, Porto Alegre, RS.
Cruz, C. D. 2013. GENES - a software package for analysis in experimental statistics and quantitative genetics. Acta Scientiarum $35: 271-276$

Embrapa - Empresa Brasileira de Pesquisa Agropecuária. 2013. Sistema Brasileiro de Classificação de Solos. 3.ed. CNPS, Rio de Janeiro, RJ.

Fonseca, D. M. and Martuscello, J. A. 2010. Plantas forrageiras. UFV, Viçosa, MG.

Kuraparthy, V.; Sood, S.; Dhaliwal, H.S.; Chhuneja, P. and Gill, B.S 2007. Identification and mapping of a tiller inhibition gene (tin3) in wheat. Theoretical and Applied Genetics 114:285-294.

Lopes, R. R. and Franke, L. B. 2011a. Produção de sementes de quatro ecótipos de Paspalum nativos do Rio Grande do Sul. Revista Brasileira de Zootecnia 40:20-30.

Lopes, R. R. and Franke, L. B. 2011b. Correlação e análise do coeficiente de trilha dos componentes do rendimento de sementes de grama-forquilha. Revista Brasileira Zootecnia 40:972-977.

Martiniello, P. and Silva, J. A. T. 2011. Physiological and bioagronomical aspects involved in growth and yield components of cultivated forage species in mediterranean environments: a review. The European Journal of Plant Science and Biotechnology 5:64-68.

Melo, L. C.; Melo, P. G. S.; Faria, L. C.; Diaz, J. L. C.; Del Peloso, M. J.; Rava, C. A. and Costa, J. G. C. 2007. Interação com ambientes e estabilidade de genótipos de feijoeiro-comum na Região CentroSul do Brasil. Pesquisa Agropecuária Brasileira 42:715-723.

Moore, K. J.; Boote, K. J. and Sanderson, M. A. 2004. Physiology and developmental morphology. p.179-215. In: Moser, L. E.; Burson, B. L.; Sollenberger, L. E., eds. Warm-season $\left(\mathrm{C}_{4}\right)$ grasses. American Society of Agronomy, Madison.

Nakagawa, J. 2014. Os componentes da produtividade de sementes. Informativo Abrates 24:15-21.

Pereira, E. A. 2013. Melhoramento genético por meio de hibridizações interespecíficas no grupo Plicatula - Gênero Paspalum. Universidade Federal do Rio Grande do Sul. Rio Grande do Sul, Porto Alegre.

Pereira, E. A.; Barros, T.; Volkmann, G. K.; Battisti, G. K.; Silva, J. A. G.; Simioni, C. and Dall'Agnol, M. 2012. Variabilidade genética de caracteres forrageiros em Paspalum. Pesquisa Agropecuária Brasileira 47:1533-1540.

Pereira, E. A.; Dall'Agnol, M.; Nabinger, C.; Hubber, K. G. C.; Montardo, D. P. and Genro, T. C. M. 2011. Produção agronômica de uma coleção de acessos de Paspalum nicorae Parodi. Revista Brasileira de Zootecnia 40:498-508.

Pereira, E. A.; Dall'Agnol, M.; Schneider, R.; Weiler, R. L.; Kuhn, N. J. I. S.; Simioni, C.; Mazurkievicz, G. and Silva, J. A. G. 2015. Adaptabilidade e estabilidade em genótipos apomíticos do gênero Paspalum. Ciência Rural 45:1361-1367.

Quarín, C. L. and Normann, G. A. 1990. Interpecific hydris between five Paspalum species. Botanical Gazette 151:366-369.

Sadras, V. O. 2007. Evolutionary aspects of the trade-off between seed size and number in crops. Field Crops Research 100:125-138.

Sartor, M. E.; Quarin, C. L. and Espinoza, F. 2009. Mode of reproduction of colchicine-induced Paspalum plicatulum tetraploids. Crop Science 49:1270-1276.

Singh, D. 1981. The relative importance of characteres affecting genetic divergence. The Indian Journal of Genetics and Plant Breeding 41:237-245.

Souza, F. H. D. 2001. Produção de gramíneas forrageiras tropicais. Embrapa Pecuária Sudeste, São Carlos. 43p.

Wunderlin, R. P.; Hansen, B. F.; Franck, A. R. and Essig, F. B. 2016. Atlas of Florida Plants. Institute for Systematic Botany, University of South Florida. Available at: <http://florida.plantatlas.usf.edu $>$. Accessed on: July 29, 2016. 